\title{
TANAMAN INDIKATOR DAN TEKNIK RAPD-PCR UNTUK PENENTUAN BIOTIPE BEMISIA TABACI GENNADIUS (HEMIPTERA: ALEYRODIDAE)
}

\author{
Purnama Hidayat $^{1}$, Noor Aidawati ${ }^{2}$, Sri Hendrastuti Hidayat ${ }^{1}$ dan $^{\text {Dewi Sartiami }}{ }^{1}$
}

\begin{abstract}
Indicator Plant and PCR-RAPD for Biotype Determination of Bemisia tabaci Gennadius (Hemiptera: Aleyrodidae). $B$. tabaci has been known world wide as a major pest and virus vector of horticulture. In Indonesia the presence of $B$. tabaci was reported since 1980 and its role as virus vector in tomato and chilli pepper has becoming more important recently. Genetic diversity of $B$. tabaci has been well recognized, but very little information available for diversity of $B$. tabaci in Indonesia. This research was conducted in Bogor, West Java from May 2004 to June 2005. The aim of this research was to initiate basic information regarding genetic diversity of B. tabaci in Indonesia, particularly in Java Island. Whiteflies population collected from different crops, i.e. tomato, broccoli, chill pepper, eggplant, cucumber, soybean, and edamame, was evaluated using silverleaf-induction test, and RAPD-PCR. It was evidenced that only B. tabaci population from broccoli was able to induce silverleaf. Two genetic types of $B$. tabaci, i.e. biotype B and non B, were identified based on polymorphism character of DNA. Population from broccoli was belong to biotype B, whereas other populations from tomato, chill pepper, eggplant, cucumber, soybean, and edamame were belong to biotype non B.
\end{abstract}

Key words : Begomovirus, biotipe, RAPD-PCR, Bemisia tabaci

\section{PENDAHULUAN}

Bemisia tabaci Gennadius (Hemiptera: Aleyrodidae) (kutukebul), merupakan hama yang penting di daerah tropik dan subtropik di dunia. Kerusakan tanaman karena aktivitas makan B. tabaci dan ekskresi embun madu yang dihasilkannya dapat mengakibatkan kehilangan hasil lebih dari 50\% (Byrne \& Bellows 1991). Di samping itu B. tabaci merupakan vektor beberapa virus tanaman, di antaranya kelompok Begomovirus atau Geminivirus (Brown 1994).

Pada tahun 1980-an B. tabaci pernah dilaporkan menyebabkan serangan yang cukup merugikan pada tanaman kedelai di Indramayu, Purworejo, dan Wonosari, serta pada tanaman kacang hijau di Cirebon dan Lampung Tengah (Saranga 1985). Selanjutnya pada awal tahun 2000 dilaporkan adanya serangan $B$. tabaci pada pertanaman tomat, cabai dan kedelai di daerah Bogor, Cianjur dan Sukabumi (Yuliani 2002). Populasi B. tabaci yang ditemukan pada pertanaman tomat dan cabai tersebut tampaknya berhubungan dengan adanya serangan Begomovirus. Rata-rata jumlah B. tabaci pada tanaman cabai dan tomat berturut-turut 20 - 70 ekor dan 10 - 40 ekor tiap tanaman, dengan persentase serangan Begomovirus berturut-turut $100 \%$ dan $60 \%$. Hasil penelitian tersebut menunjukkan adanya perbedaan kemampuan
B. tabaci beradaptasi dengan tanaman inang dan kemampuan dalam menularkan Begomovirus. Adanya perbedaan tersebut kemungkinan disebabkan oleh perbedaan biotipe $B$. tabaci.

Keanekaragaman genetik antar populasi $B$. tabaci di alam telah dilaporkan (Costa \& Brown 1991; Brown et al. 1995a). Sampai saat ini diketahui ada sekitar 20 biotipe $B$. tabaci yang telah terindentifikasi dengan tingkat karakter yang berbeda. Beberapa biotipe tersebut mempunyai kisaran inang dan distribusi geografis yang terbatas, tetapi biotipe B, memiliki kisaran inang dan sebaran geografis yang paling luas, serta menghasilkan fitotoksin yang dapat menginduksi warna daun tanaman labu menjadi keperak-perakan (silverleaf) (Bedford et al. 1994). Pada saat ini, pengujian berdasarkan sifat molekuler telah digunakan untuk membedakan beberapa populasi B. tabaci. Teknik yang banyak digunakan adalah Random Amplified Polymorphism DNA (RAPD) - Polymerase Chain Reaction (PCR) untuk mengamplifikasi berbagai fragmen di dalam genom $B$. tabaci. Perring et al. (1993) menggunakan RAPDPCR untuk menunjukkan perbedaan antara B. tabaci biotipe A dan biotipe B. Hasil yang mirip juga dilaporkan oleh Gawel \& Bartlett (1993) untuk menunjukkan bahwa B. tabaci biotipe A dan biotipe B sangat mudah dibedakan dengan RAPD - PCR.

\footnotetext{
${ }^{1}$ Departemen Proteksi Tanaman, Fakultas Pertanian, IPB, Jl. Kamper, Kampus IPB Darmaga, Bogor 16680, e-mail : purnamahidayat@gmail.com

${ }^{2}$ Jurusan Hama dan Penyakit Tumbuhan, Fakultas Pertanian, Universitas Lambung Mangkurat, Jl. Jenderal A. Yani Km. 36, Banjarbaru, 70714
} 
Karena biotipe B. tabaci di Indonesia belum banyak diketahui, perlu dilakukan penelitian untuk mendapatkan informasi tentang jenis biotipe $B$. tabaci yang merupakan vektor Begomovirus penyebab penyakit pada tanaman-tanaman penting di Indonesia.

\section{METODE PENELITIAN}

Pengumpulan kutukebul. Sampel kutukebul, yang terdiri atas puparium, larva, dan imago, diperoleh dari beberapa lokasi pertanaman sayuran. Pengkajian ciri morfologi dilakukan terhadap sampel puparium yang melekat pada jaringan daun tanaman. Puparium dilepaskan dari jaringan daun secara perlahan-lahan menggunakan jarum bertangkai yang tipis, dan dilakukan di bawah mikroskop binokuler. Puparium yang sudah terlepas dari jaringan daun disimpan dalam alkohol $70 \%$ hingga siap untuk diawetkan dalam bentuk preparat mikroskop. Larva atau imago yang diperoleh disimpan dalam freezer untuk pengkajian ciri molekuler dengan metode RAPD-PCR

Pembuatan preparat mikroskop. Puparium hasil koleksi dimasukkan ke dalam tabung reaksi yang berisi alkohol 95\%. Selanjutnya ke dalam tabung reaksi ditambahkan larutan $\mathrm{KOH} 10 \%$ secara hatihati, kemudian tabung reaksi dipanaskan selama 5-10 menit (sampai puparium menjadi transparan). Setelah dicuci dengan akuades sebanyak 2 kali, puparium dimasukkan ke dalam alkohol 50\% selama 10 menit, kemudian ditambahkan 3 tetes asam fuchsin. Setelah 20 menit, ditambahkan satu tetes asam asetat glasial. Selanjutnya 10 menit kemudian puparium dimasukkan ke dalam alkohol 80\%, didiamkan 5-10 menit, lalu dimasukkan ke dalam alkohol absolut selama 10 menit. Setelah itu puparium dimasukkan ke dalam asam asetat glasial selama 10 menit, kemudian larutan diganti lagi dengan alkohol absolut selama 5-10 menit. Selanjutnya puparium dimasukkan ke dalam carbol xylene selama 1 menit, dan larutan diganti lagi dengan alkohol absolut selama 5-10 menit. Tahap terakhir, puparium dimasukkan ke dalam minyak cengkeh selama 10 menit, kemudian dipindahkan ke gelas objek dan diberi canada balsam. Setelah ditutup dengan gelas penutup preparat puparium dikeringkan di atas pemanas. Identifikasi dilakukan di bawah mikroskop fase kontras dengan menggunakan panduan kunci identifikasi Martin (1987).
Uji kemampuan menginduksi daun labu menjadi berwarna keperakan. Keragaman populasi kutukebul yang ditemukan diuji menggunakan tanaman indikator yaitu tanaman labu (Cucurbita pepo var. Blackjack). Sebanyak 100 imago kutukebul dari masing-masing populasi diinfestasikan secara terpisah ke tanaman labu yang mempunyai dua hingga tiga daun. Imago dibiarkan selama 3 hari untuk meletakkan telur, kemudian imago dimatikan. Tanaman labu yang sudah terinfestasi telur kutukebul dipelihara dan diamati perkembangan warna daunnya. Tanaman labu yang tidak diinfestasi imago kutukebul digunakan sebagai kontrol. Pengujian diulang masing-masing sebanyak 3 kali.

Amplifikasi DNA kutukebul dengan teknik RAPDPCR. Imago kutukebul yang telah diidentifikasi secara morfologi digunakan sebagai bahan analisis. Sebagai pembanding digunakan sampel kutukebul $B$. tabaci biotipe B (BtBIOTIPE_B) dan Q (BtBIOTIPE_Q) yang diperoleh dari Department of Virus Research, John Innes Centre, Norwich, UK. Ekstraksi total DNA kutukebul dilakukan dengan menggunakan serangga tunggal mengikuti metode Goodwin et al. (1994). Serangga ditempatkan pada tabung mikro dan ditambahkan kedalamnya 125 ul bufer ekstraksi CTAB [CTAB 2\%, NaCL 1.4 M, Tris$\mathrm{HCl} 100 \mathrm{mM}$, EDTA $20 \mathrm{mM}$ dan Polyvinylpyrrolidone-40 1\%]. Serangga digerus menggunakan pistil mikro plastik, divorteks, dan diinkubasi pada $65^{\circ} \mathrm{C}$ selama 5 menit. Setelah itu ditambahkan 125 ul kloroform : isoamil alkohol (24:1) dan diinkubasi pada suhu ruang selama 20 menit. Selanjutnya tabung disentrifugasi pada 800 rpm selama 5 menit. Supernatan dipindahkan ke dalam tabung mikro baru dan ditambahkan 10 ul $\mathrm{NaOAc} 3 \mathrm{M}$ (pH 5.2) dan 250 ul etanol absolut ($20^{\circ} \mathrm{C}$ ), kemudian diinkubasi selama 30 menit pada suhu $-20^{\circ} \mathrm{C}$. Setelah sentrifugasi pada $11.500 \mathrm{rpm}$ selama 15 menit supernatan dibuang dan pelet dicuci dengan etanol $70 \%$. Selanjutnya pelet DNA dikeringkan dalam pompa vakum selama 10 menit sebelum ditambahkan 10 ul air steril. DNA hasil ekstraksi diamplifikasi dengan teknik PCR berdasarkan metode Gawel \& Bartlet (1993) menggunakan primer random P5 Amershams Bioscience (5' AACGCGCAAC 3'). Setiap reaksi PCR (25 ul) terdiri atas 5 ul DNA templet, 1 ul primer (10uM), Taq polymerase 1 unit, Tris-HCL 10mM (pH 
9.0), $\mathrm{KCl} 50 \mathrm{mM}$, MgCl2 $3 \mathrm{mM}$, dNTP masingmasing $400 \mathrm{uM}$. Amplifikasi DNA dilakukan sebanyak 45 siklus melalui tahapan : $92^{\circ} \mathrm{C}$ selama 1 menit, $35^{\circ} \mathrm{C}$ selama 1 menit, dan $73^{\circ} \mathrm{C}$ selama 2 menit. Khusus untuk siklus terakhir ditambah 7 menit, dan siklus berakhir dengan suhu $4^{0} \mathrm{C}$. Fragmen DNA hasil amplifikasi PCR dielektroforesis pada gel agarosa 1,5\% dalam $1 \mathrm{X}$ bufer TBE (Tris-borate EDTA) pada tegangan 85 volt. Setelah diberi warna dengan etidium bromida gel agarosa diamati dengan UV transiluminator.

Analisis keanekaragaman kutukebul. Pola pita DNA hasil RAPD-PCR digunakan untuk mempelajari keanekaragaman kutukebul, yaitu melalui program Numerical Taxonomy and Multivariate Analysis System (NTSYS) versi 2.1 dengan metode pengelompokan Unweighted Pair Group Method with Arithmetic Mean (UPGMA) dan jarak euclidean (Rohlf 2000).

\section{HASIL DAN PEMBAHASAN}

\section{Hasil}

Identifikasi kutukebul secara morfologi. Hasil identifikasi preparat puparium kutukebul yang didapat dari pertanaman dengan menggunakan kunci identifikasi Martin (1987) menunjukkan bahwa populasi kutukebul yang ditemukan, terdiri atas 2 spesies, yaitu B. tabaci dan Trialeurodes vaporariorum (Tabel 1). Ciri spesifik yang menunjukkan bahwa kutukebul tersebut $B$. tabaci adalah berupa seta kaudal yang kokoh yang biasanya sama panjang dengan vasiform orifice, dan tidak banyaknya variasi diantara individu. Vasiform orifice lebih panjang dari alur kaudal (caudal furrow) dan bagian samping orifice tersebut hampir lurus (Gambar 1).

Kemampuan populasi kutukebul menginduksi daun labu menjadi berwarna keperakan. Hasil pengujian menunjukkan bahwa $B$. tabaci yang berasal dari brokoli mampu menginduksi daun labu menjadi berwarna keperakan (DP) sedangkan populasi lainnya tidak menimbulkan gejala DP (Gambar 2). Perubahan warna daun labu menjadi keperakan mulai terlihat 14 - 20 hari setelah tanaman labu tersebut terinfestasi populasi B. tabaci. Perubahan warna tersebut terjadi pada daun-daun muda yang baru muncul, sedangkan daun-daun yang lebih tua tetap berwarna hijau.

Analisis keanekaragaman kutukebul berdasarkan RAPD-PCR. Hasil amplifikasi total DNA dengan metode RAPD-PCR menggunakan primer P5 menunjukkan adanya polimorfisme antara 7 populasi B. tabaci. Selain pita DNA dengan ukuran yang

Tabel 1. Hasil identifikasi kutukebul yang berasal dari beberapa tanaman inang

\begin{tabular}{lcccc}
\hline $\begin{array}{l}\text { Kode } \\
\text { Populasi }\end{array}$ & Asal Lokasi & Tanaman Inang & $\begin{array}{c}\text { Identifikasi morfologi } \\
\text { puparium }\end{array}$ & Uji Daun Keperakan ${ }^{*}$ \\
\hline BtKKJT & Kediri, Jawa Timur & Terung & B. tabaci & - \\
BtBsBJB & Bogor, Jawa Barat & Brokoli & B. tabaci & + \\
BtCkBJB & Bogor, Jawa Barat & Cabai & B. tabaci & - \\
BtCb1BJB & Bogor, Jawa Barat & Tomat & B. tabaci & - \\
BtCb2BJB & Bogor, Jawa Barat & Kedelai & B. tabaci & - \\
BtBbBJB & Bogor, Jawa Barat & Edamame & B. tabaci & - \\
BtBPJB & Purwakarta, Jawa Barat & Timun & B. tabaci & - \\
BtCtBJB & Bogor, Jawa Barat & Tomat & T. vaporariorum & - \\
\end{tabular}

*) Uji daun keperakan dilakukan melalui infestasi kutukebul ke tanaman labu (C. pepo var. Blackjack). Reaksi tanaman labu adalah : (-) tidak terjadi perubahan warna daun; (+) daun berubah menjadi berwarna keperakan. 


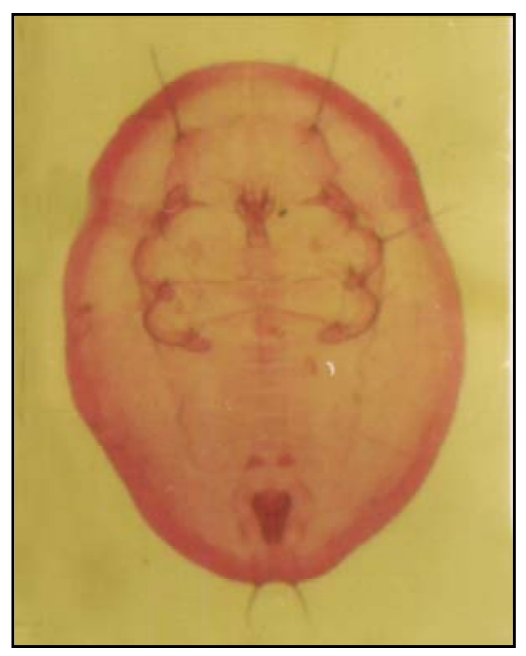

A

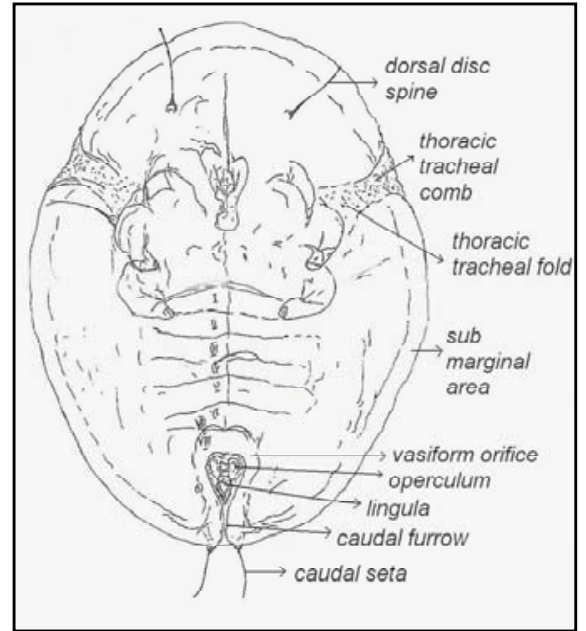

B

Gambar 1. Puparium B. tabaci (skala 1:90): (A) Preparat mikroskop; (B) Gambar garis Puparium.

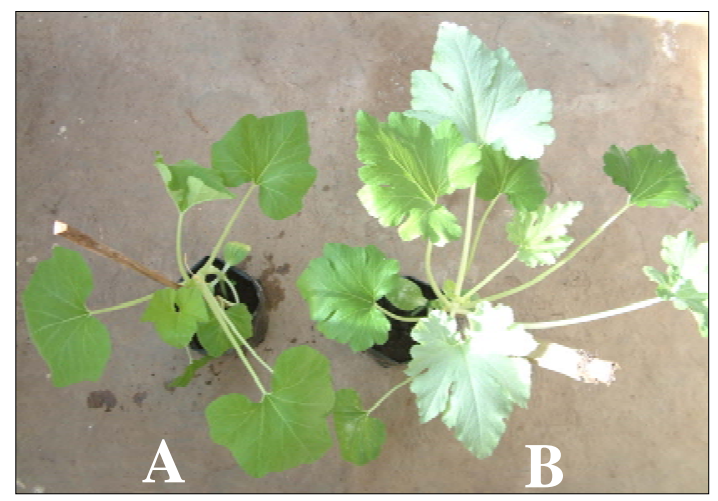

Gambar 2. Tanaman labu (C. pepo var. Blackjack) yang digunakan sebagai tanaman indikator : (A) tanaman diinfestasi dengan populasi B. tabaci asal cabai; (B) tanaman diinfestasi dengan populasi B. tabaci asal brokoli dan menunjukkan warna keperakan.

berbeda-beda, pita DNA berukuran 510 bp, 800 bp, dan 1000 bp selalu ditemukan pada semua sampel B. tabaci. Pola pita DNA yang sama ditemukan pada sampel B. tabaci asal brokoli (BtBsBJB) dan sampel $B$. tabaci biotipe $\mathrm{B}$ pembanding dari John Innes Centre, Norwich, UK (BtBIOTIPE_B) (Gambar 3). Hasil analisis UPGMA untuk nilai koefisien perbedaan jarak ketidaksamaan yang didasarkan pada 20 karakter RAPD-PCR menunjukkan bahwa pada koefisien perbedaan 5,89 B. tabaci terbagi menjadi 2 kelompok (Gambar 4). Kelompok pertama terbagi atas 2 sub kelompok, yaitu B. tabaci biotipe B dan $B$. tabaci asal brokoli dalam sub kelompok pertama, $B$. tabaci biotipe Q dan B. tabaci asal edamame dalam sub kelompok kedua. Kelompok kedua terbagi atas 4 sub kelompok, yaitu B. tabaci asal cabai dan asal kedelai dalam sub kelompok pertama, B. tabaci asal timun dalam sub kelompok kedua, B. tabaci asal 


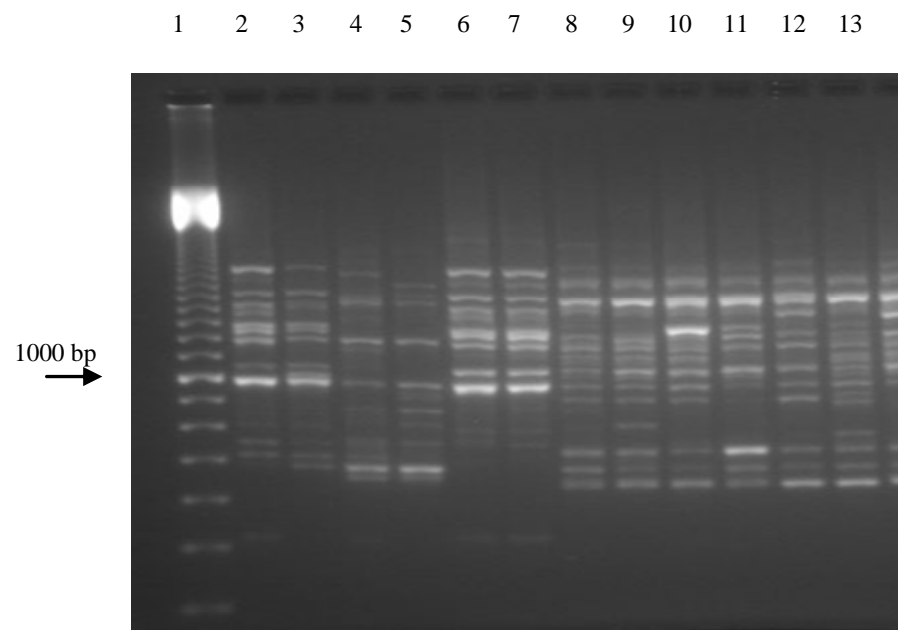

Gambar 3. Hasil RAPD-PCR menggunakan primer P5 : (1) penanda DNA; (2) dan (3) B. tabaci biotipe B; (4) dan (5) B. tabaci biotipe Q; (6) dan (7) B. tabaci asal brokoli; (8) dan (9) B. tabaci asal cabai; (10) dan (11) B. tabaci asal mentimun; (12) dan (13) B. tabaci asal tomat.

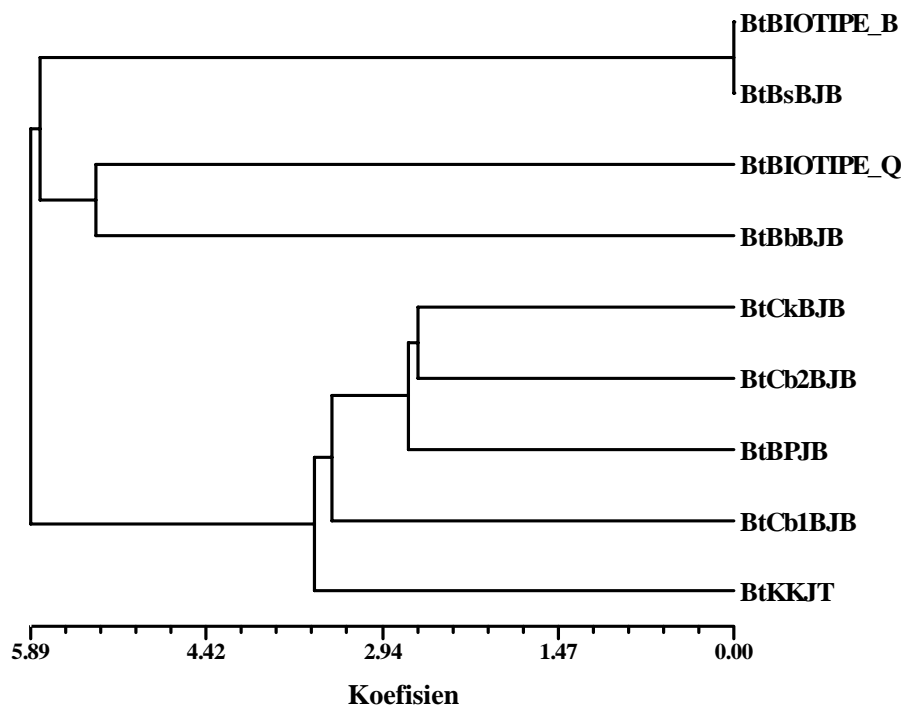

Gambar 4. Dendogram B. tabaci biotipe B, B. tabaci biotipe Q dan populasi B. tabaci dari beberapa tanaman berdasarkan ciri molekuler hasil RAPD-PCR. BtBIOTIPE_B: Sampel B. tabaci biotipe B dari John Innes Centre, Norwich, UK; BtBsBJB: B. tabaci, Brokoli, Bogor; BtBIOTIPE_Q: Sampel B. tabaci biotipe Q dari John Innes Centre, Norwich, UK; BtBbBJB: B. tabaci, Edamame, Bogor; BtCkBJB: B. tabaci, Cabai, Bogor; BtCb2BJB: B. tabaci, Kedelai, Bogor; BtBPJB: B. tabaci, Timun, Purwakarta; BtCb1BJB: B. tabaci, Tomat, Bogor; BtKKJT: B. tabaci, Terung, Kediri. 
tomat dalam sub kelompok ketiga, dan B. tabaci asal terong dalam sub kelompok keempat.

\section{Pembahasan}

Berdasarkan kemampuan menginduksi warna keperakan pada tanaman labu dibuktikan bahwa populasi B. tabaci terdiri dari dua tipe genetik. Populasi B. tabaci asal mentimun, kedelai, tomat, cabai, edamame dan terung tidak mampu menginduksi warna keperakan pada tanaman labu, sedangkan populasi B. tabaci asal brokoli mampu menginduksi warna keperakan. Menurut Brown et al. (1995b) kutukebul yang mampu menginduksi warna keperakan merupakan kutukebul daun perak (silverleaf whitefly) atau B. tabaci biotipe B. Sebelumnya Bellows et al. (1994) mendeskripsikan B. tabaci biotipe B tersebut sebagai spesies baru dan diberi nama $B$. argentifolii Bellows \& Perring, sedangkan B. tabaci yang tidak menimbulkan warna keperakan pada tanaman labu disebut sebagai kutukebul ubijalar (sweetpotato whitefly) atau B. tabaci non B.

Perubahan daun labu menjadi keperakan merupakan tanggap tanaman labu terhadap induksi sistemik oleh nimfa kutukebul daun perak, sedangkan imago kutukebul daun perak dan imago atau nimfa kutukebul ubijalar tidak menginduksi daun keperakan (Yokomi et al. 1990; Costa et al. 1993). Yokomi et al. (1990) menduga penyebab terjadinya warna keperakan pada daun labu adalah karena adanya toksin yang dihasilkan oleh nimfa yang ditranslokasi ke titik tumbuh tanaman labu. Apabila daun yang mengandung nimfa dipotong maka warna daun labu yang baru akan normal kembali.

Dua kelompok B. tabaci tersebut di atas selanjutnya dianalisis berdasarkan pola pita DNA hasil amplifikasi dengan teknik RAPD-PCR. Hasil analisis pola pita DNA menguatkan hasil uji tanaman indikator. Populasi B. tabaci yang menginduksi daun keperakan, yaitu populasi asal brokoli (BtBsBJB), ternyata berada satu kelompok dengan $B$. tabaci biotipe $\mathrm{B}$ sementara populasi yang lainnya membentuk kelompok terpisah. Penelitian dengan menggunakan teknik RAPD-PCR telah banyak digunakan untuk menentukan kemiripan dan perbedaan biotipe $B$. tabaci yang ada di dunia (De Barro \& Driver 1997; Lima et al. 2000; Horowitz et al. 2003). Perring et al. (1993) menunjukkan adanya perbedaan hasil amplifikasi antara B. tabaci biotipe A dan biotipe B dan menunjukkan tingkat kemiripan pola pita 90\% didalam setiap biotipe, tetapi tingkat kemiripan hanya $10 \%$ antar biotipe. Dengan teknik yang sama Gawel dan Bartlett (1993) berhasil membedakan biotipe A dan biotipe B dan menunjukkan bahwa penanda PCRRAPD untuk membedakan biotipe B. tabaci lebih fleksibel dibandingkan dengan isozyme, karena kemampuannya untuk membedakan biotipe dengan menggunakan semua tingkat hidup serangga dan spesimen serangga yang telah mati atau yang telah disimpan beberapa tahun dalam bentuk kering maupun yang disimpan dalam alkohol.

Selain diketahui bahwa populasi B. tabaci asal brokoli memiliki hubungan kekerabatan dengan $B$. tabaci biotipe $\mathrm{B}$, diketahui pula bahwa populasi $B$. tabaci asal edamame, Bogor (BtBbBJB) memiliki hubungan kekerabatan dengan B. tabaci biotipe Q. Hubungan kekerabatan populasi $B$. tabaci yang lain perlu diteliti lebih lanjut untuk menguatkan bukti adanya keanekaragaman kutukebul di Indonesia.

\section{SIMPULAN}

Melalui uji tanaman indikator dan analisis molekuler menggunakan RAPD-PCR dibuktikan bahwa $B$. tabaci yang berasal dari beberapa tanaman sayuran di pulau Jawa dapat dibedakan menjadi 2 tipe genetik yaitu biotipe B dan non B. Dari 7 populasi yang diuji hanya terdapat 1 populasi, yaitu $B$. tabaci asal tanaman brokoli dari Bogor Jawa Barat, yang tergolong biotipe B. Mengingat peranannya yang sangat penting dalam penyebaran penyakit tanaman, keanekaragaman B. tabaci perlu dipelajari lebih lanjut dengan melibatkan lebih banyak sampel serangga dari lokasi geografi maupun tanaman inang yang berbeda.

\section{SANWACANA}

Ucapan terima kasih penulis tujukan kepada Direktorat Jendral Pendidikan Tinggi Departemen Pendidikan Nasional yang telah mendanai kajian keragaman kutukebul melalui Hibah Penelitian Dasar 2004. Penghargaan penulis sampaikan pada Dr. Ian Bedford dari Department of Virus Research, John Innes Centre, Norwich, UK yang telah mengirimkan sampel serangga B. tabaci biotipe B dan Q. 


\section{DAFTAR PUSTAKA}

Bedford, I.D., R.W. Briddon, J.K. Brown, R.C. Rosell, P.G. Markham. 1994. Geminivirus transmission and biological characterisation of Bemisia tabaci (Gennadius) biotypes from different geographic regions. Ann. Appl. Biol. 125: 311-325.

Bellows, J.R.T.S., T.M. Perring, R.J. Gill, D.H. Headrick. 1994. Description of a species of Bemisia (Homoptera: Aleyrodidae). Ann. Entomol. Soc. Am. 87: 195-206.

Brown, J.K. 1994. Current status of Bemisia tabaci as a plant pest and virus vector in agro-ecosystems worldwide. FAO Plant Prot. Bull. 42: 3-32.

Brown, J.K., D. Frohlich, R. Rossel. 1995a. Characterization and distribution of esterase electromorphs in the whitefly, Bemisia tabaci (Genn.) (Homoptera: Aleyrodidae). Biochem. Gen. 33: 205-214.

Brown, J.K., D. Frohlich, R. Rosell. 1995b. The sweetpotato silverleaf whiteflies: biotype of Bemisia tabaci (Genn.), or a species complexs. Annu. Rev. Entomol. 40: 511-534.

Byrne, D.N., T.S. Bellows. 1991. Whitefly biology. Ann. Rev. Entomol. 36: 431-457.

Costa, H.S., J.K. Brown, S. Sivasupramaniam, J. Bird. 1993. Regional distribution, insecticide resistance and reciprocal crosses between the 'A' and 'B' biotypes of Bemisia tabaci. Insect. Scie. and Appl. 14: 127-138.

Costa, H.S., J.K. Brown. 1991. Variation in biological characteristics and esterase patterns among population with silverleaf symptom induction. Entomol. Exp. Appl. 61: 211-219.

De Barro, P.J., F. Driver. 1997. Use of PCR-RAPD to distinguish the $\mathrm{B}$ biotype from other biotypes of Bemisia tabaci (Gennadius) (Hemiptera: Aleyrodidae). Aust. J. Entomol. 36: 149-152.

Gawel, N.J., A.C. Bartlett. 1993. Characterization of differences between whiteflies using RAPDPCR. Insect Mol. Biol. 2 (1): 33-38.
Goodwin R.H., B.G. Xue, C.R. Kuske, M.K. Sears. 1994. Amplification of plasmid DNA to detect plant pathogenic mycoplasmalike organisms. Ann. Appl. Biol. 124: 27-36.

Horowitz, A.R., I. Denholm, K. Gorman, J.L. Cenis, S. Kontsedalov, I. Ishaaya. 2003. Biotype Q of Bemisia tabaci identified in Israel. Phytoparasitica 31(1) 94-98.

Lima, L.H.C., M.C. Moretzohn, M.R.V. Oliveira. 2000. Survey of Bemisia tabaci (Gennadius) (Hemiptera: Aleyrodidae) biotype in Brazil using RAPD markers. Genet. Mol. Biol. 23: 15.

Martin, J.H. 1987. An identification guide to common whitefly pest species of the world (Homoptera : Aleyrodidae). Trop. Pest Manag. 33(4): 298 322.

Perring, T.M., A.D. Cooper, R.J. Rodriguez, C.A. Farrar, T.S. Bellows Jr. 1993. Identification of a whitefly species by genomic and behavioural studies. Science 259: 74-77.

Rohlf, F.J. 2000. NTSYSpc. Numerical Taxonomy and Multivariate Analysis System. Exeter software. New York, USA. 39 hlm.

Saranga, A.P. 1985. Pengaruh varietas dan umur kedelai terhadap pola prilaku dan pertumbuhan populasi Bemisia tabaci Genn. (Homoptera: Aleyrodidae) [Tesis]. Bogor: Program Pascasarjana, Institut Pertanian Bogor.

Yokomi, R.K., K.A. Hoelmer, L.S. Osborne. 1990. Relationships between the sweet potato whitefly and the squash silverleaf disorder. Phytopathol. 80: 895-900.

Yuliani. 2002. Keanekaragaman spesies kutu kebul (Hemiptera: Aleyrodidae) pada tanaman cabai, tomat dan kedelai di Bogor, Cianjur dan Sukabumi. [Tesis]. Bogor: Program Pascasarjana, Institut Pertanian Bogor. 